\title{
Erzurum ilinde Kırım Kongo kanamalı ateş sendromuyla izlenen çocuk hastaların geriye dönük olarak değerlendirmesi
}

\author{
Retrospective evaluation of children with Crimean-Congo hemorrhagic fever syndrome \\ in the city of Erzurum
}

\author{
Soner Sertan Kara, Meltem Polat
}

\section{Özet}

Amaç:Kırım Kongo Kanamalı Ateş sendromu (KKKA) ülkemizde endemik olarak görülen bir viral kanamalı ateş hastalığıdır. Bu çalışmada KKKA tanısı konulmuş çocuk hastaların klinik ve laboratuvar özelliklerinin incelenmesi amaçlanmıştır.

Gereç ve yöntem: Bu çalışmada 01 Ocak 2015-31 Aralık 2016 tarihleri arasında KKKA tanısı konulan çocuk hastaların kayıtları geriye dönük olarak incelendi.

Bulgular:Çalışmaya yaşları ortalama 11.2ะ3.3 yıl olan toplam 17 hasta (16 erkek, 1 kız) dahil edildi. Hastaneye başvurular Nisan-Ağustos ayları arasındaydı ve en sık başvuru ( $n=5, \% 29.4)$ Temmuz ayında görüldü. Hastaların \%64.7'si şehir merkezinde yaşamaktaydı. Hastalık bulaşı en sık $(n=12, \% 70.6)$ kene ısırığıyla olmuştu. Kene ısırığı sonrası hastalarda ortalama $3 \pm 1.6$ gün sonra semptomlar başlamıştı. Hastaların toplam semptom süresi ortalama 9.8 \pm 3.4 gündü. Tüm hastaların başvuru sırasında ateşi mevcuttu. Başvuru anındaki laboratuvar incelemelerinde tüm hastalarda lökopeni ve trombositopeni mevcuttu. Onbeş (\%88.2) hastanın karaciğer enzimlerinde yükseklik, 13 (\%76.5) hastanın koagülasyon testlerinde bozukluk saptandı. Dokuz (\%52.9) hastaya taze donmuş plazma, 5 'ine (\%29.4) trombosit süspansiyonu verildi. Ribavirin tedavisi 2 (\%12) hastada kullanıldı. Dört (\%23.5) hastada komplikasyon görüldü. İki hastada batında asit, 1 hastada minimal plevral efüzyon gelişti. Hemofagositik sendrom, dissemine intravasküler koagülasyon ve kapiller kaçak sendromu gelişen bir (\%6) hasta kaybedildi.

Sonuç: Endemik bölgede yaşayan ve kene ısırığı olan çocuk hastalarda ateş ve beraberinde lökopeni, trombositopeni, artmış karaciğer enzimleri ve kreatin kinaz düzeyleri, bozulmuş koagülasyon parametreleri gibi laboratuvar bulguları varlığında KKKA akla gelmelidir.

Anahtar sözcükler: Çocuk, endemik, Erzurum, Kırım-Kongo kanamalı ateşi

Kara SS, Polat M. Erzurum ilinde Kırım Kongo kanamalı ateş sendromuyla izlenen çocuk hastaların geriye dönük olarak değerlendirmesi. Pam Tıp Derg 2018;11(3);209-214.

\begin{abstract}
Purpose:Crimean-Congo hemorrhagic fever syndrome (CCHF) is a viral hemorrhagic febrile disease that is endemic in Turkey. The aim of this study was to investigate the clinical and laboratory characteristics of children diagnosed with CCHF.

Materials and methods:In this study, records of children diagnosed with CCHFwere examined retrospectively between January 01, 2015 and December 31, 2015.

Results:Seventeen patients (16 male, 1 female), with a mean age of $11.2 \pm 3.3$ years, were included in our study. Hospital admissions occurred between April and August, most frequently during July ( $n=5,29.4 \%$ ), and $64.7 \%$ of patients were living in the city center. Disease transmission was most commonly by tick bite $(n=12,70.6 \%)$. Onset of symptoms occurred a mean $3 \pm 1.6$ days after tick bites. Mean total symptom duration was $9.8 \pm 3.4$ days. All patients were pyretic, leukopenic, and thrombocytopenic on admission. Fifteen (88.2\%) patients had elevated liver enzymes and $13(76.5 \%)$ had coagulation parameter abnormalities. Nine (52.9\%) patients received fresh frozen plasma, and $5(29.4 \%)$ received thrombocyte suspensions. Ribavirin therapy was used in $2(12 \%)$ patients. Complications were seen in $4(23.5 \%)$ patients. Two patients had abdominal ascites and one had minimal pleural effusion. One (6\%) patient with hemophagocytic syndrome, disseminated intravascular coagulation, and capillary leak syndrome died.

Conclusion: Fever and accompanying laboratory parameters including leukopenia, thrombocytopenia, elevated liver enzymes and creatine kinase, impaired bleeding parameters should suggest CCHF in pediatric patients living in endemic regions and tick bite.
\end{abstract}

Key words: Child, endemic, Erzurum, Crimean-Congo hemorrhagic fever

Kara SS, Polat M. Retrospective evaluation of children with Crimean-Congo hemorrhagic fever syndrome in the city of Erzurum. Pam Med J 2018;11(3):209-214.

Soner Sertan Kara, Uzm.Dr. Erzurum Bölge Eğitim Ve Araştırma Hastanesi, Çocuk Enfeksiyon Hastalıkları Kliniği, ERZURUM, e-posta: drsoner@yahoo.com (orcid.org/ 0000-0002-8129-6063) (Sorumlu yazar)

Meltem Polat, Uzm.Dr. Erzurum Bölge Eğitim Ve Araştırma Hastanesi, Çocuk Enfeksiyon Hastalıkları Kliniği, ERZURUM, e-posta: meltemtemizhan@gmail.com (orcid.org/0000-0002-4608-1286) 


\section{Giriş}

Kırım Kongo kanamalı ateşi (KKKA), kenelerle bulaşan ve insanlarda sıklıkla kanama bulguları ile seyreden ağır ve ölümcül bir hastalıktır. Hastalığın etkeni olan KKKA virüsü, Bunyaviridae ailesinin Nairovirus türündendir. KKKA virüsü, başta Hyalomma marginatum marginatum olmak üzere, Hyalomma cinsi keneler tarafından taşınır. İnsanlara virüsün bulaşması; kene tarafından ısırılma, enfeksiyonun akut fazındaki KKKA'ı hastayla temas ya da viremik çiftlik hayvanlarının kan veya enfekte dokuları ile temas sonucu olmaktadır. KKKA özellikle Afrika, Asya, Doğu Avrupa ve Orta Doğu'daki ülkelerde endemik olarak görülmektedir [1, 2]. Hastalık, Türkiye'de ilk kez 2002 yılında görülmüştür. Hastalığın prevalansı yıllar içerisinde giderek artmış ve Sağlık Bakanlığı verilerine göre ülkemizde 2017 yılına dek yaklaşık 10.000 olgu saptanmıştır [3].

KKKA, tüm yaş gruplarında görülebilmekle birlikte çocuklarda prevalansı düşüktür [4]. Literatürde KKKA'nın klinik ve laboratuvar bulgularının değerlendirildiği çalışmaların çoğu erişkinlere ait olup sınırlı sayıda çocuk çalışması mevcuttur [4-7]. Doğu Anadolu bölgesi KKKA açısından endemik bölgelerden biri olup [8-10], hastanemiz Erzurum ve çevre illerdeki KKKA'lı olguların direk başvurduğu ya da sevk edildiği bir referans hastanesidir. Bu çalışmada Erzurum ve çevresindeki illerden hastanemize başvuran ve KKKA tanısı konulan çocuk hastaların demografik, klinik ve laboratuvar özelliklerinin incelenmesi amaçlanmıştır.

\section{Gereç ve yöntem}

Bu çalışmada, 01 Ocak 2015-31 Aralık 2016 tarihleri arasında Çocuk Enfeksiyon Hastalıkları kliniğimize KKKA ön tanısıyla yatan ve KKKA virüs IgM ve/veya real-time polimeraz zincir reaksiyon (RT-PZR) testi pozitif saptanan çocuk hastaların (<18 yaş) kayıtları geriye dönük olarak incelendi. Hastaların serum örneklerinden KKKA virüs RT-PZR (QiagenR CCHFV Viral RNA Kit, Qiagen, Hilden, Almanya) ve indirekt immünofloresan test yöntemiyle KKKA virüs IgM testleri Erzurum Halk Sağlığı Laboratuvarı'nda çalışıldı. Çalışmanın etik kurul onayı Erzurum Bölge Eğitim ve Araştırma Hastanesi etik kurulundan alındı (onay no: 2016/02-27).

Hastalara ait demografik, klinik (başvuru belirti ve bulguları, gelişen komplikasyonlar, uygulanan tedaviler ve sonuçları) ve laboratuvar bulgular [tam kan sayımı; C-reaktif protein (CRP) değeri; karaciğer enzim testleri: aspartat aminotransferaz (AST), alanin aminotransferaz (ALT), gama glutamil transferaz (GGT); laktat dehidrogenaz (LDH) ve kreatin fosfokinaz (CPK) düzeyi; koagülasyon testleri: aktive parsiyel tromboplastin zamanı (aPTT), protrombin zamanı (PT) ve international normalized ratio (INR) testleri] hastane bilgisayar sisteminden

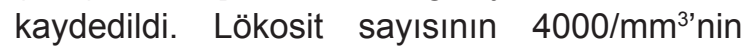
altında olması lökopeni, trombosit sayısının $150,000 \mathrm{~mm}^{3}$ 'nin altında olması trombositopeni olarak tanımlandı.

Verilere ait istatistiksel analizler Statistical Package for the Social Sciences 17.0 (SPSS Inc., Chicago, IL, ABD) paket programı yardımıyla yapıldı. Değişkenlerin normal dağılıma uygunluğu Kolmogrov-Smirnov/ Shapiro-Wilk testleri ile incelendi. Sayısal veriler ortalama \pm standart sapma veya ortanca (minimum-maksimum), kategorik veriler ise sayı ve yüzde olarak ifade edildi.

\section{Bulgular}

Çalışmaya yaş ortalaması $11.2 \pm 3.3$ yıl olan toplam 17 hasta (16 erkek, $1 \mathrm{kIz}$ ) dahil edildi. Hastaların demografik ve klinik bulguları Tablo 1 'de özetlenmiştir. Hastaneye başvurular Nisan ve Ağustos ayları arasındaydı ve en sık (\%29.4) başvuru Temmuz ayında oldu. Hastaların çoğu ( $n=12, \% 70.6)$ Erzurum ve ilçelerinden gelmekteydi. Erzurum dışından gelen hastaların en sık başvurduğu ay ise Mayıs ayı ( $n=2, \% 11.7)$ oldu.

Hiçbir hastanın altta yatan kronik bir hastalığı yoktu. On iki (\%70.6) hastada kene ısırı̆ı̆ varken, bir (\%5.9) hastanın KKKA hastalığı olan bireyle teması mevcuttu. Dört (\%23.5) hastanın ise endemik bölgede yaşamak dışında bildirilen bir risk faktörü yoktu. Kene ısırığı en sık gövde (\%41.6) ve üst ekstremitelerdeydi (\%33.3). Kene ısırığı olan hastalarda kene ısırığı farkedildikten ortalama $3 \pm 1.6$ gün sonra ilk belirtilerin ortaya çıktığı görüldü. Hastaların toplam belirti süresi ortalama $9.8 \pm 3.4$ gündü. Tüm hastalarda başvuru sırasında ateş mevcutken, diğer en sık belirti halsizlikti ( $n=14, \% 82.4)$. Tüm hastaların başvuru anındaki laboratuvar incelemelerinde lökopeni ve trombositopeni mevcuttu(Tablo 2). 
Sadece 2 hastaya (\%11.8) ribavirin tedavisi (Dünya Sağlık Örgütü önerilerine uygun şekilde; $30 \mathrm{mg} / \mathrm{kg}$ yükleme dozunu takiben ilk 4 gün $15 \mathrm{mg} / \mathrm{kg} / \mathrm{doz}$ her 6 saatte bir, sonraki 6 gün boyunca 7,5 mg/kg/doz her 6 saatte bir) verildi [11]. Dört (\%23.5) hastanın izlemi sırasında komplikasyon görüldü; 2 hastada (\%11.8) batında asit, 1 hastada (\%5.9) plevral efüzyon ve 1 hastada (\%5.9) sekonder hemofagositik sendrom, dissemine intravasküler koagülasyon ve kapiller kaçak sendromu gelişti. Sekonder hemofagositik sendrom gelişen hastaya yatışının ikinci gününde ribavirin ve pulse steroid tedavisi verildi, ancak hasta kaybedildi. Hastaların ortalama hastanede yatış süreleri $8.6 \pm 3.0$ gündü.

\section{Tartışma}

$\mathrm{Bu}$ çalışmada KKKA hastaları için referans merkezi olan bir hastanede izlenen çocuk hastaların demografik, klinik, laboratuvar bulguları ve tedavi sonuçları incelenmiştir. Özellikle endemik bölgelerde hastalığa ait epidemiyolojik, klinik ve laboratuvar bulgularının iyi tanınması ve tanı konulan hastaların uygun şekilde yönetilmesi oldukça büyük önem taşımaktadır.

Çalışmamızda olguların çoğunun ergen yaş grubunda ve erkek olması diğer çocuk çalışmalarıyla benzer bulunmuştur [4-7]. Hastalık insanlara kene ısırığı, KKKA pozitif bir bireyle direkt temas ya da viremisi olan çiftlik hayvanlarının kan ve dokularına temas yoluyla bulaşmaktadır [1]. Bu çalışmada da hastaların çoğunluğunda hastalık bulaşıcı kene ısırığı ile olmuştur. KKKA mevsimsel bir dağılım göstermektedir. Ülkemizin de yer aldığı Kuzey yarımkürede olguların çoğu, sıcaklık artışıyla beraber kene aktivitesinde artmanın yaşandığı ilkbahar-yaz döneminde, MayısEylül ayları arasında görülmektedir [12]. Bizim çalışmamızda da hastaneye başvurular Nisan ve Ağustos ayları arasında olup, en sık başvuru Temmuz ayında olmuştur. Erzurum dışından yapılan başvuru sayısı az olsa da, başvuru aylarındaki farklılığın, olguların bulunduğu illerdeki farklı hava sıcaklıkları ve iklim koşullarıyla ilişkili olduğu düşünülmüştür.

KKKA sendromunda kuluçka dönemi, bulaş yoluna ve virüs yüküne bağlı olarak 3-7 gün arasında değişmektedir ve kene ısırığı sonrası genellikle 3 gündür [13]. Çalışmamızda da literatürle benzer olarak [1, 4] kene ısırığı farkedildikten ortalama $3 \pm 1.6$ gün sonra ilk belirtilerin ortaya çıktığı görülmüştür. KKKA'lı çocuklarda literatürde bildirilen en sık belirti ateştir $[4,5]$. Bu çalışmada da benzer şekilde tüm hastaların başvuru sırasında ateşi mevcutken, diğer çalışmalardakilerin aksine miyalji ve kusma yerine bu çalışmada diğer sık görülen belirti halsizlik olmuştur [4, 5]. Çalışmamızdaki toplam belirti ve hastanede yatış süreleri de önceki çocuk çalışmalarıyla benzer bulunmuştur $[4,6]$.

KKKA'da lökopeni ve trombositopeni hastalığın değişmez bulgularıdır ve hastalığın erken döneminde görülmektedir [1]. Diğer çocuk çalışmalarıyla benzer olarak [4, 6], tüm hastalarımızda başvuru anında lökopeni ve trombositopeni mevcuttu. KKKA'da sıkça bildirilen diğer laboratuvar anormallikleri olan karaciğer enzim, LDH, CPK yüksekliği ve koagülasyon testlerinde bozulma başvuru anında olguların büyük kısmında mevcuttu.

KKKA seyrinde hastadan hastaya değişen genetik faktörler, immünite ve virüse ait genetik farklılıklara bağlı olarak, hastalarda değişen klinik tablolar görülmektedir [14]. Hastalığın çocuklarda erişkinlere göre daha iyi seyirli olduğu düşünülse de, çocuklarda da ağır komplikasyonlar ve ölüm görülebilmektedir. Bu çalışmada hastaların \%23.5'inde komplikasyon gelişmiştir. Hastalık sırasında viremi ortadan kalktıktan sonra sitokin fırtınası da denilen, hipersitokinemi ve pansitopeninin eşlik ettiği hemofagositik sendrom ve eşlik eden damarlardan sızıntı ve kaçak gelişebilmektedir [15]. Dilber ve ark.'nın [6] yaptığı çalışmada 21 çocuk hastanın 6'sında hemofagositoz görülmüştür. Bizim çalışmamızda ise bir hastada hemofagositik sendrom, dissemine intravasküler koagülasyon ve kapiller kaçak sendromu gelişmiştir. Sağlık Bakanlığı verilerine göre 2002'de tanı alan ilk olgudan beri şimdiye dek ülkemizde KKKA tanısı alan olguların yaklaşık \%5'inin kaybedildiği görülmüştür [9]. Bu çalışmada da ölüm oranı \%5.9 olarak saptanmıştır. Ülkemizde önceki yıllarda yayınlanan çocuk çalışmalarında ise ölüm oranı \%0-4.7 arasında bulunmuştur $[4,6,7]$.

Çalışmamızın geriye dönük ve tek merkezli olması ve hasta sayısının nispeten az olması 
Tablo 1. KKKA tanısı ile izlenen hastaların klinik ve demografik özellikleri

Özellik

n (\%)

\section{Cinsiyet}

Erkek/kız

$16(94.1) / 1(5.9)$

\begin{tabular}{|c|c|}
\hline \multicolumn{2}{|l|}{ Başvuru ayları } \\
\hline Nisan & $2(11.8)$ \\
\hline Mayıs & $4(23.5)$ \\
\hline Haziran & $3(17.6)$ \\
\hline Temmuz & $5(29.4)$ \\
\hline Ağustos & $3(17.6)$ \\
\hline \multicolumn{2}{|l|}{ Geldiği yer } \\
\hline Erzurum & $12(70.5)$ \\
\hline aDiğer & $5(29.4)$ \\
\hline \multicolumn{2}{|l|}{ Yaşam yeri } \\
\hline Kırsal/köy & $6(35.3)$ \\
\hline Şehir merkezi & $11(64.7)$ \\
\hline \multicolumn{2}{|l|}{ Temas öyküsü } \\
\hline Kene ısırığı & $12(70.6)$ \\
\hline KKKA olan bireyle temas & $1(5.9)$ \\
\hline Endemik bölgede yaşama & $4(23.5)$ \\
\hline \multicolumn{2}{|l|}{ Kenenin çıkarıldığı bölge } \\
\hline Baş-boyun & $1(8.3)$ \\
\hline Üst ekstremite & $4(33.3)$ \\
\hline Alt ekstremite & $2(16.6)$ \\
\hline Gövde & $5(41,6)$ \\
\hline \multicolumn{2}{|l|}{ Basvuru anındaki yakınmalar } \\
\hline Ateş & $17(100)$ \\
\hline Halsizlik & $14(82.4)$ \\
\hline İshalıkusma & $11(64.7)$ \\
\hline Karın ağrısı & $9(52.9)$ \\
\hline Miyalji & $6(35.3)$ \\
\hline Burun akıntısı/tıkanıkığı & $5(29.4)$ \\
\hline Artralji & $2(11.8)$ \\
\hline Epistaksis & $2(11.8)$ \\
\hline Döküntü & $1(5.9)$ \\
\hline \multicolumn{2}{|l|}{ Başvuru anında fizik inceleme bulgusu } \\
\hline Tonsillofarenjit & $2(11.8)$ \\
\hline Peteşi & $2(11.8)$ \\
\hline Hepatosplenomegali & $1(5.9)$ \\
\hline \multicolumn{2}{|l|}{ İzlemi sırasında verilen tedaviler } \\
\hline Taze donmuş plazma transfüzyonu & $9(52.9)$ \\
\hline Trombosit süspansiyonu transfüzyonu & $5(29.4)$ \\
\hline K-vitamini & $1(5.9)$ \\
\hline Ribavirin tedavisi & $2(11.8)$ \\
\hline Komplikasyon varlığı & $4(23.5)$ \\
\hline \multicolumn{2}{|l|}{ Sonuç } \\
\hline İyileşme & $16(94.1)$ \\
\hline Eksitus & $1(5.9)$ \\
\hline
\end{tabular}

a: Bingöl, Erzincan, Gümüşhane 
Tablo 2. KKKA tanısı ile izlenen hastaların başvuru anındaki laboratuvar bulguları

\begin{tabular}{|c|c|}
\hline Beyaz küre $\left(/ \mathrm{mm}^{3}\right)$ (ortalama $\left.\pm S D\right)$ & $1932 \pm 822$ \\
\hline $\mathrm{Hb}(\mathrm{gr} / \mathrm{dL})$ (ortalama $\pm \mathrm{SD})$ & $12.6 \pm 1.6$ \\
\hline Trombosit $\left(/ \mathrm{mm}^{3}\right)$ (ortalama $\left.\pm S D\right)$ & $67.230 \pm 50.390$ \\
\hline CRP (0-5 mg/dL) [ortanca (min-maks)] & $1.3(0.3-12)$ \\
\hline Elektrolit bozukluğu olan hasta sayısı, n (\%) & $4(23.6)$ \\
\hline Hiponatremi $(<135 \mathrm{mEq} / \mathrm{L})$ & $2(11.8)$ \\
\hline Hipopotasemi (<3.5 mEq/L) & $2(11.8)$ \\
\hline Karaciğer enzimlerinde yükseklik olan hasta sayısı, $\mathbf{n}(\%)$ & $15(88.2)$ \\
\hline AST (5-34 U/L) [ortanca (min-maks)] & $256(24-4202)$ \\
\hline ALT (0-55 U/L) [ortanca (min-maks)] & $157(25-1801)$ \\
\hline GGT (12-64 U/L) [ortanca (min-maks)] & $91(11-430)$ \\
\hline LDH yüksekliği olan hasta sayısı n (\%) & $16(94.1)$ \\
\hline LDH (125-220 U/L) [ortanca (min-maks)] & $575(215-5303)$ \\
\hline CPK yüksekliği olan hasta sayısı n (\%) & $13(76.4)$ \\
\hline CPK (30-200 U/L) [ortanca (min-maks)] & $255(109-25312$ \\
\hline Koagülasyon testlerinde bozukluk olan hasta sayısı, n (\%) & $13(76.5)$ \\
\hline aPTT (21-35 sn) (ortalama \pm SD) & $36.8 \pm 10.7$ \\
\hline INR (0.8-1.2) (ortalama $\pm S D)$ & $1.3 \pm 0.1$ \\
\hline PTZ (10.5-14.9 sn) (ortalama $\pm S D)$ & $16.1 \pm 2.1$ \\
\hline
\end{tabular}

nedeniyle çalışma sonuçlarının genellenmesi zordur. Ancak hastalığın endemik olduğu Doğu Anadolu Bölgesi'nden bildirilen ilk çocuk çalışması olması nedeniyle çalışmamızın sonuçlarının literatüre katkı sağlayacağını düşünmekteyiz.

Sonuç olarak, endemik bölgede yaşayan ve kene ısırmasından kısa süre sonra ani olarak başlayan ateş, halsizlik ve laboratuvar bulgularında lökopeni, trombositopeni, koagülasyon testlerinde bozulma, karaciğer enzimleri ve CPK düzeylerinde yükseklik saptanan çocuk hastalarda KKKA akla gelmelidir.

Çıkar İlişkisi: Yazarlar çıkar ilişkisi olmadığını beyan eder.

\section{Kaynaklar}

1. Ergönül $O$. Crimean-Congo haemorrhagic fever. Lancet Infect Dis 2006;6:203-214.

2. Messina JP, Pigott DM, Golding N, et al. The global distribution of Crimean-Congo hemorrhagic fever. Trans R Soc Trop Med Hyg 2015;109:503-513.
3. T.C. Sağlık Bakanlığı Halk Sağlığı Genel Müdürlüğü. Zoonotik ve Vektörel Hastalıklar Daire Başkanlığı İstatistiksel Verileri. Ulaşım adresi: http://www.thsk. gov.tr/component/k2/353-istatiksel-veriler/zoonotik-vevektorel-hastaliklar-daire-baskanligi-istatiksel-verileri. html. Erişim tarihi: 01 Ekim 2017.

4. Belet N, Top A, Terzi O, Arslan HN, Baysal K, Sensoy G. Evaluation of children with CrimeanCongo hemorrhagic fever in the central Blacksea region. Pediatr Infect Dis J 2014;33:194-197.

5. Tuygun N, Tanir G, Caglayik DY, Uyar Y, Korukluoglu G, Cenesiz F. Pediatric cases of Crimean-Congo hemorrhagic fever in Turkey. Pediatr Int 2012;54:402406.

6. Aslani D, Salehi-Vaziri M, Baniasadi V, et al. CrimeanCongo hemorrhagic fever among children in Iran. Arch Virol 2017; 162:721-725.

7. Dilber E, Cakir M, Acar EA, et al. Crimean-Congo haemorrhagic fever among children in north-eastern Turkey. Ann Trop Paediatr 2009;29:23-28.

8. Bayram Y,Parlak $M, \quad$ Özkaçmaz $A$, et al. Seroprevalence of CrimeanCongo hemorrhagic fever in Turkey's Van province. Jpn J Infect Dis 2017;70:65-68.

9. Leblebicioglu H, Ozaras R, Irmak H, Sencan I. CrimeanCongo hemorrhagic fever in Turkey: Current status and future challenges. Antiviral Res 2016;126:21-34. 
10. Cikman A, Aydin M, Gulhan B, et al. Seroprevalence of Crimean-Congo Hemorrhagic fever virus in Erzincan province, Turkey, relationship with geographic features and risk factors. Vector Borne Zoonotic Dis 2016;16:199-204.

11. World Health Organization. Crimean-Congo hemorrhagic fever. Available at: www.who.int/inf-fs/ fact208.html. Erişim tarihi: 05 Ekim 2017.

12. Tasdelen Fisgin N, Doganci L, Tanyel E, Tulek N. Initial high rate of misdiagnosis in Crimean Congo haemorr hagic fever patients in an endemic region of Turkey. Epidemiol Infect 2010;138:139-144.

13. Shayan S, Bokaean M, Shahrivar MR, Chinikar S. Crimean-Congo Hemorrhagic Fever. Lab Med 2015;46:180-189.

14. Demir ZC, Bastug A, Bodur H, Ergunay K, Ozkul A. MicroRNA expression profiles in patients with acute Crimean Congo hemorrhagic fever reveal possible adjustments to cellular pathways. J Med Virol 2017;89:417-422.

15. Papa A, Tsergouli K, Çağlayık DY, et al. Cytokines as biomarkers of Crimean-Congo hemorrhagic fever. J Med Virol 2016;88:21-27. 